\title{
A GDP, A HDI, A GNH ÉS AZ OECD INDIKÁTORRENDSZERE MINT A FENNTARTHATÓ FEJLŐDÉS INDIKÁTORAI
}

\author{
Dr. PhD. Kotosz Balázs ${ }^{1}$ \\ ${ }^{1}$ föiskolai docens, Szegedi Tudományegyetem, Mérnöki Kar
}

\begin{abstract}
SUMMARY
Sustainable development has been an important focus of current researches. To be able to test the theories, to develop goals, and to control their fulfillment we need measurement. The three main fields of sustainable development (economic, societal and ecological) have a series of indicators, but these indicators are not always applicable to achieve the above-mentioned goals. In the paper, we survey the requirements of the indicators absed on a wide-range literature, whether they are real and consistent ones, their possible weights in the three fields. After theoretical part, we analyze some wellknown measure to show that even these measures can be criticized. We conclude that none of the above mentioned measures are perfect ones, and sometimes the most criticized measures show better performance.

Kulcsszavak: fenntartható fejlổdés, indikátor rendszerek
\end{abstract}

\section{BEVEZETÉS}

A fenntartható fejlödés vizsgálata korunk aktuális és sokat kutatott problémája. Ahhoz, hogy az elméletek helyességét ellenörizni tudjuk, célokat tudjunk kitüzni és azok megvalósulását kontrollálni, szükség van mérésre. A fenntartható fejlödés három nagy területének (gazdasági, társadalmi, természeti) számos indikátorát alakították ki, azonban ezek egy része kevéssé alkalmas a célok elérésére. A tanulmányban azt vizsgáljuk, hogy milyen követelményeknek kell megfelelnie az alkalmas indikátoroknak. Kitérünk arra, hogy a követelmények mennyire reálisak és konzisztensek, a három területen azonos súllyal figyelembe vehetök-e. Az elméleti vizsgálódást néhány szélesebb körben indikátornak tekintett mutató tesztelésével egészítjük ki, jelezve azt, hogy még a széles körben elfogadott mutatók sem képesek önmagukban megfelelni alapvető elvárásoknak, ugyanakkor a leginkább elfogadott mutatók számos esetben nagyon távol állnak az elvárásoktól.

\section{A FENNTARTHATÓ FEJLŐDÉSRŐL}

A fenntartható fejlődés fogalmának is sokféle megközelítése ismert. Bár egyes tanulmányok csak egyes területeket vizsgálnak, alapvetően három nézöpontot különithetünk el: a gazdasági, a társadalmi és a környezeti szempontokat (ld. 1. ábra). A három nézőpont a fejlődést eltérő módon értelmezi, így gazdasági szempontból gyakori a növekedés elötérbe helyezése, míg környezeti szempontból az állandóság és a status quo fenntartása hangsúlyosabb lehet. A fenntarthatóság mindhárom nézőpontból önállóan is értelmezhető és modellezhetö, a gazdasági nézőpont elsősorban közgazdasági modellek stabilitásán alapul, a társadalmi fenntarthatóság demográfiai és szociológiai egyensúlyt vizsgál, míg a környezeti oldal az élölények életfeltételeinek hosszú távú fennmaradására.

Az egyik legáltalánosabban elfogadott definíció szerint (Defra National Statistics, 2010), a fenntartható fejlödés úgy teszi lehetővé az embereknek szükségleteik kielégítését és egy jobb életminőség élvezetét, hogy azzal nem rontják a következő generációk életminőségét.

Az indikátorok fontosságát az ENSZ is kiemeli: "A fenntartható fejlödés indikátorait ki kell dolgozni annak érdekében, hogy megbízható alapjául szolgálhassanak a döntéshozatalnak minden szinten, és hogy az integrált környezet és fejlesztési rendszerek 
önszabályozó fenntarthatóságához hozzájáruljanak.” United Nations (1992, Agenda 21, Chapter 40.4)

A mérőszámok az egyes területeken általában alapadatok, amelyek közvetlenül mérhetőek vagy megfigyelhetőek (pl. szén-dioxid kibocsátás mennyisége, gépkocsik száma, közúti balesetek száma, halálozási arányszám). Két-két terület kombinációja számos egyszerübb indikátort is lehetővé tesz, de sok esetben egymással már nehezen összemérhető változók összegzésén vagy hányadosán alapul, addig a három nézőpontot ötvöző fenntartható fejlődési indikátorok lényegében kompozit mutatók, amelyeket alapmutatókból hoznak létre, egyszerủ lineáris kombinációval, vagy sokváltozós adattömörítő eljárásokkal.

1. ábra: A fenntartható fejlődés nézőpontjai

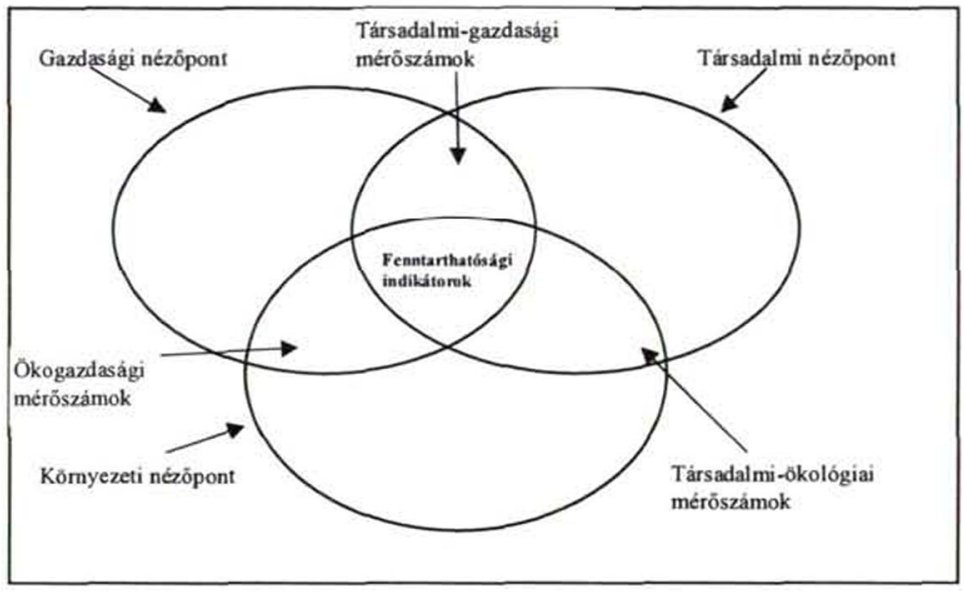

Forrás: Saját szerkesztés Sikdar, 2003 alapján

\section{AZ INDIKÁTOROKKAL SZEMBEN TÁMASZTOTT KÖVETELMÉNY- RENDSZER}

Amint Meadows (1998) összefoglalja, egy jó indikátor, mérték vagy index legalább az alábbi 15 tulajdonsággal rendelkezik:

Világos értékítélet: nincs bizonytalanság azzal kapcsolatban, hogy melyik irány a pozitív, és melyik a negatív változás.

Tartalmilag világos: könnyen értelmezhető, értelemmel bíró egységekben mér, elképzelhető, nem megtévesztő számokat ad eredményül.

Lenyügöző: érdekes, izgalmas, szuggesztív és cselekvésre ösztönző.

Politikailag releváns: a rendszer összes érintettje számára, ideértve a legalacsonyabb befolyással lévöket is.

Megvalósitható: ésszerü költségekkel mérhető.

Elégséges: nem foglal magában túl sok információt, de nem is túl keveset ahhoz, hogy a helyzetet megfelelő módon leírja.

Időszerü: hosszú késedelem nélkül meghatározható.

Nagyságrendje megfelelő: nincsen sem alul-, sem felülaggregálva.

Demokratikus: az indikátor kiválasztásába be kell vonni az embereket és az eredményekhez hozzáférést kell biztosítani.

Kiegészítő: olyan információkat kell tartalmaznia, amelyeket az emberek saját maguk nem tudnak mérni (pl. rádióaktiv sugárzás, müholdképek) 
Részvételen alapuló: olyan információkat is kell tartalmaznia, amelyeket az emberek maguk is mérni tudnak (folyóvizek minősége, biodiverzitás), valamint felhasználhatnak térbeli és időbeli összehasonlitásra.

Hierarchikus: a felhasználó képes a részletek kibontására, de az általános üzenetet gyorsan megértheti.

Fizikai: a pénz és az árak zajosak, inflálódnak, csúszósak és instabilan változékonyak. Mivel a fenntartható fejlödés döntő részben fizikai dolgokhoz - élelem, víz, szennyezőanyagok, erdők, házak, egészség - kötődik, a lehető legjobb megoldás fizikai egységekben mérni (pl. olaj tonnában és nem dollárban, az egészségben töltött évek száma az egészségre forditott kiadások helyett).

Vezető: időben információt biztosít ahhoz, hogy akciók alapjául szolgáljon.

Rugalmas: nyitott a vitára, tanulásra és változásra.

A fenti követelmények sokrétủen fedik le az elvárásokat, részint átfedik egymást (pl. időszerü és vezetö, vagy lenyügöző és vezetö), részint kissé ellentmondóak (pl. kiegészitő és részvételen alapuló, vagy tartalmilag világos és rugalmas). Szinte egyértelmü, hogy nincs olyan indikátor, amely valamennyi követelményt egyszerre tudná teljesíteni, különösen feltünö ez a megvalósitható-kiegészitö-részvételen alapuló-fizikai négyszögben, hiszen az emberek által közvetlenül mérhető és nem mérhetö információk összegzése fizikai egységekben már önmagában sem mindig megoldható, mindezt költséghatékonyan elvégezni pedig csaknem lehetetlen.

Prescott-Allen (2001) mindössze három követelményt fogalmazott meg az ideális indikátorokkal szemben, ugyanakkor megjegyzi, hogy még ezt a három követelményt sem mindig lehet egyszerre teljesíteni, így a kutató kompromisszumokra kényszerül:

Reprezentatív: a vizsgált tényező valamennyi fontos aspektusát lefedi, megmutatja az időbeli trendeket és a helyek és embercsoportok közti különbségeket

Megbízható: közvetlenül jelzi, hogy a kivánt célt mennyire sikerült elérni; jól megalapozott, precíz, standardizált módon mér, látványos és konzisztens mintavételi eljáráson alapul. nyugszik.

Megvalósítható: már rendelkezésre álló vagy ésszerủ költségekkel elérhető adatokon

Vegyük észre, hogy az első két követelmény legalább 5 alapkövetelmény integrálásából származik. A Prescott-Allen-féle követelményeket - a mintavételi eljárásra alapozás kivételével - a Meadows-féle rendszer is tartalmazza.

\section{A GDP, A HDI, A GNH ÉS AZ OECD INDIKÁTORAINAK ELEMZÉSE}

Az indikátorok kapcsán folyamatos viták tárgyát képezi, hogy a rendszer alapvetöen sok, önáló indikátoron alapuljon vagy ezekből valamilyen kompozit indikátor elkészitése a célravezetöbb. Az önálló indikátorok általában önmagukban jobban megfigyelhetöek, mérhetöek, értelmezhetőek, de számosságuk és közvetlen összehasonlithatatlanságuk miatt a fejlödés megitélésére sem alkalmazhatóak (értelmezhetö-e fejlödésnek az, ha 67 indikátor nött, 1 csökkent?). A kompozit indikátorok esetén ez a probléma nem merül fel, viszont elöállitásuk során a mutatók eredeti tartalma több-kevésbé elvész (vagy egyszerüen visszakódolhatatlanná válik - súlyozásos módszerek esetén, vagy az adattartalom egy része is elvész - dimenziócsökkentö eljárások esetén). Elsőként 3 kompozit indikátort vizsgálunk, majd az $\mathrm{OECD}$ egyszerü indikátorrendszerét vesszük górcső alá.

A fenntartható fejlődés gazdasági indikátorai közül kiemelkedő szerepe van a gazdasági teljesítmény mérésének. A makrogazdasági modellek kulcsváltozója általában a makrojövedelem, amelyet a makrogazdaság szereplöi által szerzett összes jövedelemként, 
termelési oldalról pedig a hozzáadott értékek összegeként lehet definiálni, így lényegében a Bruttó Hazai Termék (Gross Domestic Product - GDP) megfelelöje (United Nations, 2009). A makrojövedelem növekedési pályája a növekedéselmélet kulcskérdése, így a gazdasági nézőpontból vett fenntarthatóság egyik indikátora. Jóléti értelemben általában az egy före jutó értéket használják. Az ezzel kapcsolatos kritikákról Dasgupta (2007) vagy England (1997) munkájában bövebben olvashatunk.

A GDP a 3. pontban ismertetett követelmények túlnyomó részét nem teljesíti. Mivel a teljes makrogazdaság teljesitményét összegzi, az átlagos felhasználó számára nem áttekinthető, lassan számítható (ráadásul túlnyomórészt becslésen és nem mérésen alapul), pénzben mér, és számítása meglehetősen konzervatív. Értékitélete évtizedeken keresztül világosnak tünt, bár a Stiglitz-bizottság létrehozása (az okokról ld. Stiglitz et al, 2009) ezt is megkérdőjelezi.

A Humán Fejlettségi Indexet (Human Development Index - HDI) éppen a GDP hiányosságainak ellensúlyozására hozta létre az ENSZ 1990-ben. A HDI a jólét három dimenzióját ragadja meg (zárójelben az alapindikátor):

- hosszú és egészséges élet (születéskor várható élettartam)

- tudás (írni-olvasni tudó felnőttek aránya és a bruttó beiskolázási arány)

- megfelelö életszínvonal (1 före jutó GDP vásárlóerö-paritáson)

A mutatók értékét első lépésben a 0-1 skálára normálják, majd a három normált mutató egyszerü számtani átlaga adja a HDI-t. Látható, hogy az ilyen módon képzett indikátor a gazdasági nézőponton túl a társadalmi nézőpontot is figyelembe veszi, ugyanakkor a GDP-nél összetettebb mutató, a GDP összes hátrányával, úgy, hogy a végeredményül kapott érték még a GDP-nél is nehezebben értelmezhetö. (Bleys, 2005)

A Bruttó Nemzeti Boldogság (Gross National Happiness - GNH) a bhutáni uralkodó kezdeményezésére készült indikátor, amely 9 terület (pszichológiai jólét, egészség, oktatás, kultúra, idöfelhasználás, jó kormányzás, közösségi élet, ökológiai diverzitás és rugalmasság) 33 indikátorát tartalmazza. (Bates, 2009) A mutató elsősorban a társadalmi fenntarthatóság elemeit tartalmazza, de az utolsó terület az ökológiai nézőpont néhány mutatóját is tartalmazza. Számitása kérdöives felmérésen alapul, a 33 indikátor a kérdőiv 72 kérdésére adott válaszokból tevődik össze (ebböl 60 kvalitativ, míg 12 kvantitatív választ vár). A követelmények szemszögéböl tekintve a Prescott-Allen hármas kritériumrendszert viszonylag jól teljesíti, és a Meadows-féle kritériumrendszert is zömében kielégíti (bár a mutató alapján szükséges intézkedések nehezen vagy alig olvashatók ki az eredményekből - gondoljunk itt a pszichológiai jólét vagy az időfelhasználás mérlegére).

Az OECD indikátorainak magját az 1. és a 2. táblázatban közöljük. A felsorolt indikátorok jelentős része a mindennapokban nem mérhetỏ adatokon alapul (pl. folyó fizetési mérleg adatai), míg a környezettel kapcsolatos mutatók egy része csak becsléssel (sokszor csak igen nagyvonalú becsléssel) határozható meg (pl. légnemủ szennyezőanyagok kibocsátása). Azt is jól érzékeltetik, hogy az alapmutatók szintjén is igen sok proxy változó szerepel. Kiemelten jó példa erre a biodiverzitás, ahol nem az állat- vagy növényfajok száma, azok változása szerepel, hanem egy igen egyszerüen megállapítható, azonban a biodiverzitással alig korreláló mutató, a védett területek aránya. Önmagában a védettség - bár vannak efelé mutató tendenciák - nem növeli a biológiai sokszinűséget. A humán töke állomány nagyságára is kétségtelenül jelentös hatást gyakorol az oktatás, de nem kizárólag a felsöfokú oktatás. Ilyen értelemben a Prescott-Allen kritériumok is csak részben teljesülnek, jórészt a költséghatékonyságot valósítja meg (olyan mutatók szerepelnek benne, amelyeket az OECD már korábban is gyüjtött, így külön adatgyüjtés nem szükséges). 
1. táblázat: A fenntartható fejlődés erőforrás-indikátorainak alapkészlete

\begin{tabular}{|c|c|}
\hline Téma & Indikátor \\
\hline \multicolumn{2}{|l|}{ Környezeti eszközök } \\
\hline \multirow{3}{*}{ Levegōminöség } & Üvegházhatású gázok kibocsátási indexe \\
\hline & $\mathrm{CO}_{2}$ kibocsátás \\
\hline & $\mathrm{NO}_{\mathrm{x}}$ kibocsátás \\
\hline Víz & Vízhasználat intenzitás (kitermelés/megújuló készlet) \\
\hline Energia & Energia erőforrások felhasználása \\
\hline Biodiverzitás & Védett területek aránya az összes területből \\
\hline \multicolumn{2}{|l|}{ Gazdasági eszközök } \\
\hline Elôáallított eszközök & A nettó tökeállomány \\
\hline $\mathrm{K}+\mathrm{F}$ eszközök & Többtényezös termelékenység növekedési ráta \\
\hline Pénzügyi eszközök & $\begin{array}{c}\text { Nettó külföldi követelések és a folyó fizetési mérleg } \\
\text { egyenlege }\end{array}$ \\
\hline \multicolumn{2}{|l|}{ Humán tôke } \\
\hline Humán tôke állomány & A felsőfokú végzettségüek aránya \\
\hline Humán tõke beruházás & Oktatási kiadások \\
\hline $\begin{array}{l}\text { A humán tôke } \\
\text { amortizációja }\end{array}$ & Munkanélküliség szintje és aránya \\
\hline
\end{tabular}

Forrás: Saját szerkesztés Stevens, 2005 alapján

2. táblázat: A fenntartható fejlődés kimenet-indikátorainak alapkészlete

\begin{tabular}{|c|c|}
\hline$\underline{\text { Téma }}$ & Indikátor \\
\hline Fogyasztás & $\begin{array}{l}\text { A háztartások végsō fogyasztási kiadásai } \\
\text { Helyi hulladék keletkezés intenzitása }\end{array}$ \\
\hline Jövedelem eloszlás & Gini együttható \\
\hline Egészség & Születéskor várható élettartam \\
\hline Foglalkortatás & Város levegố minōsége \\
\hline Oktatás & Részvételi arány az oktatásban \\
\hline
\end{tabular}

Forrás: Saját szerkesztés Stevens, 2005 alapján

\section{5. ÖSSZEFOGLALÁS}

A tanulmányban a meglehetősen összetett fenntartható fejlődés mérésének néhány aspektusát vizsgáltuk. A mérésnek alapvetően két irányzata van: egyrészt egyes szerzök és mühelyek az egyes részterületek önálló mérésére törekednek, széleskörü indikátorrendszer segítségével, míg mások kompozit indikátorok kiszámításával igyekeznek a problémát megoldani. Más célokat képes szolgálni az egyik és a másik megoldás, azonban bizonyos alapvető gondok mindkét esetben felmerülnek. Meadows és Prescott-Allen szempontjai alapján megállapíthatjuk, hogy a mérés általános problémáin túl az indikátorokkal szemben támasztott követelmények teljesitése mindkét típusú vizsgálat esetén nehézségekbe ütközik. A tanulmányban bemutatott mutatók közül a tudományos körökben legtöbb kétséggel fogadott Bruttó Nemzeti Boldogság bizonyult a legtöbb kritériumnak megfelelőnek. 


\section{IRODALOMJEGYZÉK}

Bates, W. (2009): Gross national happiness. Asian-Pacific Economic Literature. 16 p.

Bleys, B. (2005): Alternative welfare measures. Kézirat, Vrije Universiteit Brussel.

Dasgupta, P. (2007): Measuring Sustainable Development: Theory and Application. Asian Development Review, vol. 24, no. 1, pp.1-10

Defra National Statistics (2010): Measuring Progress. Sustainable developmet indicators 2010. Defra National Statistics, London.

England, R. (1997): Alternatives to Gross National Product: a Critical Survey. In: Ackerman, Frank et al (eds). Human Well-Being and Economic Goals. Washington DC: Island Press, pp. 373-405.

Meadows, D. (1998): Indicators and Information Systems for Sustainable Development. The Sustainabilty Institute, Hartland.

Prescott-Allen, R. (2001): The Well-Being of Nations: A Country-by-Country Index of Quality of Life and the Environment. Island Press, Washington, DC.

Sikdar, S. K. (2003): Sustainable Development and Sustainability Metrics. AIChE Journal, Vol. 49, No. 8, pp. 1928-1932.

Stevens, C. (2005): Measuring Sustainable Development. OECD Statistics Brief. OECD, Paris.

Stiglitz, J. E., Sen, A., Fitoussi, J-P. (2009): Report by the Commission on the Measurement of Economic Performance and Social Progress. http://www.stiglitz-senfitoussi.fr/documents/rapport_anglais.pdf

United Nations (1992): Agenda 21: The United Nations Programme of Action From Rio. United Nations, New York.

United Nations (2009): System of National Accounts 2008. United Nations, New York. 